\title{
OBITUARIES
}

Prof. Thomas Alan Stephenson, F.R.S.

MARINE biologists in many lands will learn with sorrow of the death on April 3, at the age of sixty-three, of Prof. Thomas Alan Stephenson, for he had travelled widely and visited many ocean shores. Alan Stephenson's first interest was sea anemones, a group of animals which no doubt appealed to his artistic nature, and this culminated in the beautifully illustrated Ray Society monographs on British sea anemones which appeared in 1928 and 1935. He was on the staff of the Department of Zoology at University College, London, during 192230 , and in 1923 made a short investigation for the States of Guernsey on the biology of the ormer, Haliotis, with the view of legislation to check the noticeable decrease in supply.

In 1928 he joined the Great Barrier Reef Expedition under C. M. Yonge and led the shore party concerned with the ecological investigations on the reefs. His knowledge of anemones made him most suitable for this expedition, and he naturally devoted much time to the corals themselves, making also valuable observations on growth. But his wider interest in shore ecology found full scope in a general study of reef ecology, on which one of his joint papers with his wife, G. Tandy and M. Spender, will have lasting value as evidence of the state of Low Isles in that year. It has already formed the basis of two later smallscale surveys.

In 1930, Stephenson was elected to the chair of zoology in the University of Cape Town. It was then that he developed his grand idea of the comparison of shore faunas on a world-wide scale. Our knowledge of the distribution of the intertidal fauna and flora had been restricted to detailed surveys at isolated points either in easy reach of marine laboratories or at places visited by expeditions. Stephenson. was the first to organize a continuous survey along a great length of coast and its value lay in the fact that the same people saw the whole length of coast so that their observations were as comparable as possible.

This first great survey, over a period of ten years, extended from Port Nolloth on the west coast of Africa, round the Cape, to Durban on the east coast. It thus covered regions in the south Atlantic, the Southern and Indian Oceans, and extended through a range of climates as well as areas influenced by different ocean currents. The work was done with all his usual exactitude, and the correct identification of species was ensured so far as possible. The great series of papers produced by Stephenson and his colleagues will remain as a lasting memorial to a unique zoologist and as a reference point for all time. It was then that he discerned the underlying simplicity of the zonation patterns on the shore.

In 1940, he was appointed professor of zoology in the University of Wales at Aberystwyth, where he had been a student, and here he continued to inspire research on shore ecology. But every opportunity was still taken to continue his chief aim of seeing for himself as much of the coastline of the world as possible. With his wife Anne, who was always his constant and devoted collaborator, he explored the coasts of North America and of Bermuda. He was to have visited the Mediterranean this summer.

It was Alan's hope to write a book bringing together all his vast knowledge, and it is sad that he cannot now do this. But in fact a great deal has been published and is available to the world and the pioneering has been accomplished. The outburst of interest in marine science is ensuring that many more shores are being surveyed. The stimulus has been given and the standard set by Stephenson and his concept of three universal intertidal zones is being confirmed.

All Stephenson's work was characterized by its extreme finish, and everywhere could be seen his meticulous care for detail. But as well as being a first-class naturalist he was also an artist. His paintings of marine animals and plants are exquisite portrayals and their composition emphasizes his deep artistic appreciation and disclosure of pattern and rhythm, so beautifully exemplified in his little book on Seashore Life and Pattern.

The deepest sympathy of their many friends will go out to his wife in her bereavement.

F. S. Russeux

\section{Dr. Daphne Atkins}

Dr. Daphne Atkins, a familiar figure to workers at the Plymouth Laboratory during the past 35 years, died on March 1. She was born on March 4, 1896, at Oxted, Surrey, the daughter of N. E. W. and Elisa Atkins. She was educated at the Kent County School for Girls, Tunbridge Wells, and from there went on to Bedford College, London, where she took her degree, in zoology and geology, in the early nineteen twenties.

Her first visit to Plymouth was probably in 1922 when I well remember her as a fellow student at the Easter class. After graduation she was soon to return to Plymouth where, supported initially by a series of research grants, she continued to work for much of the rest of her life. Her only notable period of absence was during and for some time after the War when she returned to Oxted to care for her aged parents.

She made major contributions to our knowledge of marine invertebrates. She observed the living animal, she studied its anatomy by dissection and in sections, in exact detail she followed the course of the ciliary currents concerned with respiration, feeding and cleansing in bivalve molluses, polyzoans and brachiopods. She published her conclusions in admirably presented and most beautifully illustrated papers. These must have numbered at least forty and were largely published in the Journal of the Marine Biological Association, the Quarterly Journal of Microscopical Science and the Proceedings of the Zoological Society of London.

Her earliest research, suggested by J. H. Orton, on the moulting stages of pea-crabs (Pinnotheres) was published in 1927. While this led to further work on post-embryonic development, it had very different and far-reaching side issues. These included accounts of a fungal infection and of an entoniscid (Isopod) parasite on Pinnotheres, examples of contributions to parasitology which included descriptions of orthonectid, rhabdocol and copepod parasites in bivalves.

Observing the effects of Pinnotheres on the gills of Mytilus, she noted that the damage caused led to the appearance of secondary or supernumerary food grooves with an associated reversal of beat in the adjacent frontal cilia. This led to further work on 
abnormal gills and then on regeneration. These are very valuable papers containing information which could very suitably form the groundwork of further important studies. In the case of their author they led to a series of eight papors "On the Ciliary Mechanisms and Interrelationships of Lamellibranchs" published between 1936 and 1943 . In the course of some 400 pages she ranged widely throughout the bivalves describing and figuring in the most precise and beautifully illustrated detail the course of ciliary currents and the different types of cilia, with such matters as cuticular fusion and the nature of ctenidial musculature. These papers are an abiding source of knowledge, one to which I am glad to pay my testimony of gratitude and admiration. They put all workers on the bivalve Mollusca, now and in the future, in her debt.

Another source of interest, again initially stimulated by J. H. Orton, was in the Polyzoa. Early in her research career she published an account of their ciliary feeding mechanisms followed by a detailed systematic and anatomical account of the Loxosomatidea of the Plymouth area. Later she was to describe the structure and feeding mechanisms of cyphonautes larvæ. Her latest interest, made possible by the more extensive collecting range of the post-war research vessel, Sarsia, was in Brachiopoda with which her last seven papers, dealing with development of the lophophore, with feeding mechanisms and with systematics, are concerned.

Although of an extremely retiring disposition, Daphno Atkins was far from being devoid of personality. Within the field of her research interests she held most decided views, supported as they were by the results of years of the most careful observa. tion. She has left a magnificant monument in her long series of published papers. As the Plymouth Laboratory made her work possible, this itself is a justification for the existence of that Laboratory.

C. M. YoNGE

\section{NEWS and VIEWS}

The First American Manned Ballistic Rocket Flight

ON May 5, at 14.34 hr. U.T., a Redstone rocket was launched from Cape Canaveral in Florida, carrying Commander Alan Shepard, of the U.S. Navy, in a space capsule. This first United States attempt at manned ballistic rocket flight was entirely successful. The capsule was accelerated to a maximum speed of 5,100 miles per hour, reached a height of 115 miles and travelled 302 miles down-range over the Atlantic. As it re-entered the atmosphere the capsule's heatshield was seen from the waiting ships to be glowing red. Commander Shepard seems to have suffered no ill-effects as a result of his 15-min. flight, during which he was subjected to a deceleration of $11 \mathrm{~g}$. He was in radio communication with the ground throughout, and was able to climb out of the capsule before a helicopter arrived to pick him up. Though this rocket firing was only a first step towards orbital flight, Commander Shepard was able to test orbital techniques by controlling the orientation of the capsule under zero-gravity conditions.

\section{New Carbon Isotope, Carbon-16}

A NEW carbon isotope of mass 16 has been discovered by physicists of the Atomic Weapons Research Establishment, Aldermaston, working in collaboration with scientists of the Clarendon Labor. atory, Oxford. A carbon-14 target was bombarded with a beam of $6-\mathrm{MeV}$. tritons (ions of tritium) from the Aldermaston Van de Graaff accelerator. In some cases, the force of the collision was observed to be sufficiently great to split the triton into its constituents of one proton and two neutrons and the two neutrons were captured by the carbon-14 to form a new isotope, carbon-16. By making precise measurements with a large magnetic spectrograph on the emitted protons, the mass of the new isotope was found to be $16 \cdot 014702$ atomic mass units. It was anticipated that carbon-16 would suffer beta-decay like carbon-14 and carbon-15, but with the difference that the product of the decay would still have sufficient energy to emit a neutron. This occurred, and use was made of this property to measure the half-life, which was found to be 0.74 sec. The most abundant isotope of carbon is, of course, carbon-12. Isotopes of mass 13,14 and 15 are known, of carbon-14 and -15 are radioactive, and the former is the basis for the carbon-14 dating of archrological specimens.

\section{Ministry of Aviation : Mr. W. O. Broughton}

Mr. W. O. Brovghton has been promoted to deputy chief scientific officer and appointed to the post of director of air navigation and reconnaissance research and development in succession to Mr. C. J. Carter, who has joined the defence research staff in Washington. Mr. Broughton started his career in the Civil Service in 1935 at the Royal Aircraft Establishment, where he was engaged on development work connected with automatic pilots, the Queen Bee pilotless target aireraft and stabilized automatic bombsights. In 1942 he transferred to Headquarters, Ministry of Aircraft Production, to take charge of a section concerned with the development of automatic pilots, gyroscopes and stabilizing equipment. He returned to the Royal Aircraft Establishment in 1947 as head of the Controls Division of the Instrument and Air Photography Department, remaining in this post until 1954, when he was transferred to Headquarters, Ministry of Supply. In 1955 he was appointed assistant director, being responsible for administration of research and development connected with automatic flight control systems, automatic blind landing, flight instrument systems and aircraft fire control systems. In addition to these systems, $\mathbf{M r}$. Broughton now assumes responsibility for research and development on air photography, bombsights, flight simulators and non-radio aircraft navigation systems.

\section{Physics at Birmingham:}

Prof. W. F. Vinen

Dr. W. F. VINEN, who has been appointed to a chair of physics in the University of Birmingham at the early age of thirty-one, was educated at Watford Grammar School and Clare College, Cambridge, where he was elected to a research fellowship in 1955. In 1958, he was appointed a University demonstrator in physics and a Fellow of Pembroke College. In close collaboration with his contemporary, Dr. H. E. 